www.periodicos.unimontes.br/index.php/caminhosdahistoria

\title{
CONJUNTO SÃO MIGUEL: UMA HISTÓRIA DE LUTA PELO DIREITO À CIDADE (1978-1980)
}

\author{
Angerlânia da Costa Barros ${ }^{1}$
}

Resumo: O artigo reflete sobre o movimento de resistência à remoção pelos habitantes da antiga favela José Bastos, em Fortaleza, entre 1978 e 1980, a partir de um confronto entre a "história oficial" e propagandística advinda dos documentos administrativos do município e das publicações dos jornais O Povo e Correio do Ceará e a memória dos sujeitos diretamente envolvidos e alvo do Programa Integrado de desfavelamento. O objetivo foi perceber como o governo se utilizou dos meios de comunicação (e da tendência favorável à "remoção" dos produtores destes meios) para construir uma imagem positiva do desfavelamento e como este controle da opinião pública incidiu sobre a memória coletiva, inclusive a dos excluídos socioespacialmente, de modo que eles se reconhecem como beneficiados. O objetivo é analisar as razões que os motivaram a resistir e conhecer alguns dos sujeitos emblemáticos deste episódio de reivindicação e luta pela permanência na área e, sobretudo, pelo direito à moradia.

Palavras-chave: Periferia; Conjunto habitacional; Resistência; Ceará; Brasil.

Abstract: The article reflects on the movement of resistance to the removal by the inhabitants of the old favela José Bastos, in Fortaleza, between 1978 and 1980, based on a confrontation between the "official history" and the propaganda that came from the administrative documents of the municipality and from the publications of newspapers O Povo and Correio do Ceará and the memory of the subjects directly involved and the target of the Integrated Program for the development of urban development. The objective was to understand how the government used the media (and the favorable tendency to "remove" producers from these media) to build a positive image of the underdevelopment and how this control of public opinion affected collective memory, including that of the socio-spatially excluded, so that they recognize themselves as beneficiaries. The objective is to analyze the reasons that motivated them to resist and to know some of the emblematic subjects of this episode of claim and struggle for the permanence in the area and, above all, for the right to housing.

Keywords: Periphery; Housing; Resistance; Ceará; Brazil.

\section{Ocupação ou invasão? Como surge uma favela?}

\begin{abstract}
"Meu senhor", disse a moradora da favela ao repórter, "se existir inferno, nós estamos nele. É a José Bastos. Ninguém tem mais sossego ali. Vivemos sempre assustados, com medo dos tratores derrubarem nossos casebres, das ameaças dos vigias, com cuidado nas crianças. O pior é a incerteza. Nós não temos lugar para onde ir e eu não sei o que vai acontecer, quando o prazo dado pelo juiz terminar" (O POVO, 12/01/1979, p. 8).
\end{abstract}

\footnotetext{
${ }^{1}$ Mestre em História e Culturas, na linha de Práticas Urbanas, pela Universidade Estadual do Ceará (UECE). Email: angel_htaa@hotmail.com. Orcid: https://orcid.org/0000-0002-5415-9178.
} 
O início do ano de 1979 foi aterrorizante para os moradores da favela José Bastos, em Fortaleza, como se observa na notícia acima. Desde a ocupação de um terreno particular situado às margens da antiga Avenida José Bastos, entre setembro e outubro de 1978, até o despejo em 26 de abril de 1979, as famílias que lá se instalaram não tiveram paz. De acordo com a publicação do jornal $O P o v o^{2}$, a preocupação dividia-se, sobretudo, em três fatores: a violência policial, a expectativa sobre o direito ao lugar - ou da expulsão definitiva - e a insegurança quanto à permanência de seus casebres antes da decisão final.

Maria de Lima Carvalho, esposa de Francisco Gonçalves de Carvalho, morador que representa o símbolo da resistência à remoção, depois de receber um tiro que o acometeu de paralisia, no dia 26 de dezembro de 1978, devido à um confronto entre os moradores e policiais, conta-nos como começou a ocupação da área chamada favela José Bastos. Segundo ela, o local ocupado era um bom espaço e em alguns aspectos parecia ser abandonado, pois não possuía cercas ou muros de proteção ou qualquer outra vigilância, sendo possível ir colher frutas no terreno:

Lá era bom, o terreno era bom, até então o terreno não tinha dono, lá era abandonado e não tinha uma cerca, eu passava lá com a minha mãe e ia pegar manga, aí o meu irmão, um dia conversando com seu Vicente, que morava numa vila bem pertinho, juntou lá umas pessoas que não tinha onde morar, ai fizeram uma primeira barraca, foi só fazer uma barraca, quando o seu Vicente construiu a primeira barraca, foi até da falecida Dona Egilda, aí pronto, chegou todo mundo lá. Só sei, mulher, que da noite para o dia, tu tinha que vê o povo lá. Eles disseram que no início tinha quase umas 5.000 pessoas, mas eu não tenho certeza. A gente nunca contou ${ }^{3}$.

Esta fala de Maria Lima, quanto à ideia de apossarem-se do lugar e do início dessa ação, faz-nos concordar com Barreira, quando afirma que "[...] uma das características mais marcantes na ocupação de áreas de 'invasão' é a rapidez. Na favela José Bastos esse processo não foi diferente [...]" (1992, p. 71). Declaração reforçada também pelo O Povo, “[...] a favela da Avenida José Bastos nasceu de um dia para o outro, como acontece via de regra nestes

\footnotetext{
${ }^{2}$ Fundado em 07 de janeiro de 1928 pelo cearense Paulo Sarasate e por Demócrito Rocha, baiano que adotou o Ceará, tendo aqui se radicado e constituído família, o jornal é atualmente o órgão de imprensa mais antigo ainda em circulação no estado do Ceará. (ALVES, 2010). Seu acervo encontra-se na hemeroteca (microfilmes) da Biblioteca Pública Governador Menezes Pimentel (Espaço Estação, na Praça da Estação com Rua 24 de Maio), bem como no Instituto Histórico de Ceará, localizado na Rua Barão do Rio Branco (próximo à Avenida Duque de Caxias). Algumas notícias estão disponíveis apenas na sede do próprio Jornal, na Av. Aguanambi, 282. O jornal, desde sua fundação, se autodeclara apartidário e comprometido com a democracia e a liberdade, contudo, um de seus fundadores (Paulo Sarasate) foi Deputado Estadual e Federal, entre as décadas de 1930, 1940 e 1950. Ele também foi Governador, nos anos de 1950 e Senador pela Aliança Renovadora Nacional - ARENA, na Ditadura Militar. Depois das mortes dos fundadores, a família de Demócrito Rocha passou a administrar o noticiário, nenhum dos presidentes ocupou cargo político.

${ }^{3}$ CARVALHO, Maria de Lima. Maria de Lima Carvalho: depoimento [mai. 2017]. Entrevistadora: Angerlânia da Costa Barros. Fortaleza: 2017. Arquivo em MP4. O material foi produzido e utilizado como fonte da minha Dissertação de Mestrado, defendida em 2018.
} 
casos. Foi formada em três meses apenas. A 24 de setembro, eram levantados os primeiros casebres [...] dentro de uma semana, a favela já era uma realidade [...]” (O POVO, 15/12/1978, p. 16). Entretanto, mais velozes que a lotação desse espaço foram as críticas e as preocupações por parte dos administradores da cidade quanto ao surgimento do mesmo, pois, já em outubro, começou-se a discutir na Assembleia Legislativa qual seria o destino da área:

O deputado Almir Pinto falou na Assembleia sobre a nova favela que está surgindo no final da Avenida José Bastos, chamando a atenção das autoridades para os problemas sanitários que derivam dessa aglomeração de famílias pobres e sem qualquer noção de higiene. Segundo o deputado, nem mesmo fossas sépticas são utilizadas pelos moradores do local, havendo risco de transmissão de doenças, especialmente da esquistossomose $(\mathrm{O}$ POVO, 12/10/1978, p. 3).

Além do discurso constante sobre a questão da falta de higiene e da proliferação de doenças como fatores advindos das camadas baixas, a proposta, naquele período, quase sempre era a expulsão dessas pessoas para conjuntos habitacionais afastados dos bairros pertencentes às classes médias e altas ou destinados à especulação, “[...] o que se tem feito para enfrentar este problema só produziu injustiças: milhares de pessoas degredadas enquanto as áreas desocupadas nas zonas mais centrais caem nas mãos de empresas imobiliárias, como aconteceu na Leste-Oeste [...]" (O POVO, 12/10/1978, p. 3). Em resumo, a existência desses lugares era uma ameaça à ordem urbana, sendo vista como necessária a extinção deles a qualquer custo. Porém, dada a dificuldade de aceitação disto pelos moradores, a história de retirada dessa zona tornou-se a mais emblemática e violenta durante o final da década de 1970, em Fortaleza.

É importante compreender que esta luta pelo espaço da capital foi protagonizada por dois grupos distintos: de um lado, estavam todos aqueles (Igreja, políticos, instituições etc.) ${ }^{4}$, que consideravam a ocupação deste terreno, uma ação legítima, do outro, tinham os que viam o movimento enquanto uma invasão à propriedade privada, já que a área pertencia à uma família. Assim, para muitos, a favela nasceu de uma ocupação, para outros, porém, ela se tratou de uma invasão. O ato de ocupar, segundo Gonçalves (2006, p. 71), é um “[...] movimento de 'invasão' em imóveis abandonados, desocupados, inabitados [...]” e, invadir é

\footnotetext{
${ }^{4}$ Segundo Barreira (1992, p. 83), várias entidades e personalidades atuaram no movimento, das quais a maioria estava vinculada ao MDB, partido de oposição ao governo: Associação dos Sociólogos, Instituto dos Arquitetos do Brasil, Federação de Órgãos para a Assistência Social e Educacional, Movimento Cearense Contra a Carestia, Paróquia de São Raimundo, Diretório Acadêmico do Centro de Ciências da Saúde da UFC, Bianou de Andrade (Presidente do Diretório Municipal do MDB), José Maria de Barros Pinho (Presidente do Instituto Pedroso Horta do MDB), Joaquim de Castro Feitosa (Presidente da Sociedade Cearense da Defesa do Meio Ambiente SOCEMA), Padre Moacir Cordeiro Leite (Vigário da Paróquia de Aratuba), Deputado Federal Iranildo Pereira, Deputada Estadual Maria Luiza Fontenele de Almeida, Deputado Estadual Fausto Arruda, Professor José Ferreira de Alencar (Diretório Municipal do MDB), Instituto Pedroso Horta, do MDB.
} 
uma ocupação abusiva, forçada ou ilegal, isto é, ambas as ações denotam a apropriação de algo que não pertence ao "intruso". Dessa maneira, a diferença destes conceitos revela-se na perspectiva de quem prioriza a estética e o econômico ou o social.

Como aponta Barreira (1992, p. 72), “[...] o processo de formação da favela reflete o drama da moradia [...]". Os desprovidos de condições financeiras são vistos como ocupantes pela ótica social, entende-se que eles tomam posse de uma área "ociosa" por, muitas vezes, não terem outra opção. Já, para outros, eles são considerados uma ameaça à ordem espacial, urbanística e econômica, portanto, são tachados de invasores. Entretanto, o foco do problema não é redimir os moradores ou condená-los, mas sim, perceber as tensões provocadas pela luta em prol do direito à cidade. Em resumo, esta questão é sempre marcada pela repetição: as inexpressivas políticas habitacionais para as camadas populares não conseguem resolver a demanda de moradia, como consequência há as ocupações e estas, são chamadas de invasões, para culpar a população "invasora", ao invés dos verdadeiros responsáveis, os governantes, os especuladores imobiliários etc.

O perfil do público que ocupou o terreno em questão, segundo Irlys Barreira, era formado por trabalhadores migrantes desempregados, bem como por pessoas pobres residentes na capital que moravam de aluguel, principalmente. José Almir Monteiro Dias, um dos antigos moradores da favela José Bastos e, atualmente, do Conjunto São Miguel, fazia parte dos muitos que viram nesta ocupação a oportunidade de possuir uma moradia própria, buscando sair do inquilinato ou da casa de parentes:

Nesse tempo eu morava numa casa na Granja Portugal com uma irmã minha, aí ela disse assim: - Olha, Almir, tão invadindo uns terreno ali na José Bastos, dê um pulo lá, olhe essas coisas. Ai quando eu cheguei lá, já tinha cada qual seus pedaço, a maioria lá era pra vender os terreno, não era pra morar, ai lá eu paguei pra uma pessoa que tinha invadido. E a gente foi se apossando, né? Eu mesmo comprei um pedaço, comprei não, dei lá, nesse tempo era cinco cruzeiro, pra ter um pedaço de terra lá, pra fazer um barraco, né?

Percebe-se nesta fala que "[...] os favelados, em movimento rápido, ocuparam o espaço disponível, temerosos de que outros na mesma situação chegassem primeiro [...]" (BARREIRA, 1992, p. 72). Todavia, também existiram pessoas que se aproveitaram da situação para lucrar com a mercantilização ilegal de lotes de um terreno, que, na teoria, deveria ser compartilhado gratuitamente por todos ${ }^{6}$. Assim, se para alguns "[...] o que

\footnotetext{
${ }^{5}$ Fala de José Almir Monteiro Dias (57 anos), ex-líder comunitário do Conjunto São Miguel. Entrevista realizada em 16 de junho de 2016.

${ }^{6}$ Através das entrevistas, não é possível afirmar se houve alguma participação de grupos políticos de esquerda mobilizando as pessoas para esse tipo de intervenção social.
} 
importava mesmo era morar, assegurando um lugar para dormir e poder dessa forma, sobreviver na cidade [...]" (BARREIRA, 1992, p. 72), para outros interessava o negócio através da venda cara - o preço dos barracos ou da terra chegava a 30 mil cruzeiros - e irregular de um sonho que se tornaria pesadelo, pouco tempo depois. A compra também era motivada, em muitos casos, pelo desejo de fixar-se em um local:

Eu morei em vários lugares de Fortaleza antes de comprar a casa na Zé Basto, eu morei no Canindezinho, no São José, eu vim pra Fortaleza em 1958, vim de Ipú, lá perto de Sobral, depois né? Depois de Sobral. Antes de ir pra Zé Basto eu morava na Serrinha, eu tinha uma casa lá, aí quando a gente soube que tinha essa casa na Zé Basto, meu marido vendeu nossa casa e comprou um barraquim lá de taipa ${ }^{7}$.

Maria de Lourdes, que também morou na José Bastos, foi uma que deixou o lugar logo após o início da luta de resistência e só retornou, posteriormente, já no contexto do Conjunto São Miguel, depois do fim dos confrontos:

Mulher, a gente não invadiu, a gente comprou um barraquim lá na Zé Basto de taipa, bem baratinho. Aí quando começou o movimento de derrubada das casas, a gente saiu de lá, por causa da poeira nas crianças, e fomos morar de aluguel. Eu não queria mais morar de aluguel, ai eu resolvi vim (ao Conjunto São Miguel) $)^{8}$.

Desta fala depreendem-se três aspectos: primeiro, mostra que estas pessoas não se consideravam invasoras, negando a afirmação do advogado das proprietárias do terreno, Dr. Leônidas de Freitas, de que "[...] todos reconhecem que esbulharam a propriedade [...]" (O POVO, 16/12/1978, p. 13); segundo, sugere o conformismo diante destas situações e da ação imediata de sair do local, ao invés de contestar e resistir, como fez parte da população da área em disputa. Por último, ela reforça o ideal da casa própria ${ }^{9}$, ou seja, evidencia os desejos incessantes dos indivíduos de possuir uma moradia, sair do aluguel e sentirem-se seguros quanto ao habitar: "[...] eu tava cansada de me mudar e de morar de aluguel, queria ter minha casa própria, aí eu vim, sozinha, escondida dele (marido), e aqui no São Miguel eu descansei, aqui eu só saio se eu quiser [...]"10.

\footnotetext{
${ }^{7}$ Fala de Maria de Lourdes Rodrigues de Sousa (76 anos), antiga moradora da favela José Bastos, residente, atualmente, no Conjunto São Miguel. Entrevista realizada em 14 de julho de 2015.

${ }^{8}$ Entrevista com Maria de Lourdes Rodrigues de Sousa.

${ }^{9}$ BONDUKI (1998). Segundo Bonduki, esse ideal da casa própria e as políticas habitacionais eram destinados aos trabalhadores urbanos assalariados, porque era sobre eles que o regime varguista se apoiava. Ao incutir esse ideal no trabalhador, este já não moraria em um lugar alugado, mas se tornaria proprietário de sua casa. Ao se tornar proprietário, o trabalhador veria o quanto "o pai dos pobres" preocupava-se com ele e com a sua ascensão social.

${ }^{10}$ Entrevista com Maria de Lourdes Rodrigues de Sousa.
} 
O entusiasmo para conseguir uma moradia na área em setembro de 1978 transformouse a partir de outubro em aflição: eles tomam conhecimento de que o terreno tinha proprietárias, as quais reivindicaram a sua posse; passam a enfrentar o corretor de imóveis João Furtado, que se apresentava como representante das irmãs Ferreira, donas do território ocupado, e começam a conviver com as ameaças de despejo. As reclamações, as angústias e os episódios marcantes ocorridos durante a existência da favela José Bastos foram acompanhados e noticiados pelos jornais Correio do Ceará e O Povo. Isto porque os meios de comunicação passavam a ter uma censura menor que a do início da Ditadura e, assim, deram abertura à voz de denúncia dos menos favorecidos e, por outro lado, a Igreja, que se compadeceu da situação e se propôs a ajudá-los, também lançava muitas propostas ao Estado sobre o caso, bem como manifestava notas de repúdios às ações violentas ocorridas no local.

De acordo com Braga (1995), a luta da favela José Bastos também foi possibilitada pelo contexto político do período, pois, ao final da década de 1970, o país iniciava um processo de abertura democrática, de grandes greves como a do $\mathrm{ABC}$ paulista e de outros eventos que, paulatinamente, atraía outros setores organizados da sociedade civil brasileira para reivindicar o fim da Ditadura, da repressão e das injustiças sociais. Em outras palavras, a resistência dos moradores da José Bastos tratou-se de mais um movimento que foi de encontro ao governo repressivo e antidemocrático em que se encontrava o país. Todavia, nem mesmo o mais otimista ou pessimista "invasor" anteveria que esta simples e rápida ocupação se transformaria em um dos episódios mais relevantes (e violento) quanto ao aspecto habitacional, ocorridos em Fortaleza.

Conhecendo os processos das primeiras remoções da década de 1970 e as mudanças no contexto político-habitacional da época, podemos afirmar que a história da favela José Bastos aconteceu devido à "[...] intervenção de advogados e o papel da Igreja como mediadora e legitimadora do movimento junto à imprensa e órgãos públicos [...]" (BARREIRA, 1992, p. 75). Além disto, como aponta Irlys Barreira, “[...] o movimento da José Bastos aconteceu em um tempo no qual a marca de mudança e a busca de participação sintetizavam o slogan da rejeição à ditadura [...]” (1992, p. 73). A resistência da José Bastos foi possibilitada, apesar das reações violentas dos militares, pelo "[...] fortalecimento do movimento social organizado, que, por meio de associações de moradores e de favelas [...] buscava confrontar o poder constituído, ampliando os espaços de atuação coletiva [...]" (REIS, 2010, p. 225-226). 


\section{Resistência e luta dos moradores da favela José Bastos}

Os conflitos e a violência empregada neste processo podem ser explicados por algumas razões. De início, as primeiras demolições ocorridas em 14 de dezembro de 1978 somadas às ameaças e à presença do corretor de imóveis João Furtado deram início à mobilização de resistência, bem como ao fracasso de negociação entre o governo municipal e os moradores. A cobertura jornalística sobre a difícil situação dos habitantes da José Bastos, após esta data, ganhou visibilidade e apoio de algumas entidades como a Igreja, que passou a não somente informá-los sobre seus direitos, mas também a ajudá-los ativamente. Características que, de acordo com Beserra (2015), são intrínsecas dos mediadores: informação e participação.

Os moradores passaram a resistir à remoção e a revidar a violência recebida depois da Igreja ter se envolvido no caso. Esta contribuiu com advogados e realizou muitas reuniões na favela, conscientizando-os sobre o que poderia lhes acontecer naquele contexto e, sobretudo, indicando a quem e como reivindicar a permanência no local. $\mathrm{O}$ ato de "[...] resistir significa se reconhecer como tendo direitos constituídos [...]" (BESERRA, 2015, p. 103), isto explica o porquê de somente a partir da participação da Igreja, eles ousarem reagir contra as tentativas de despejos. O movimento também foi fruto da experiência de organização coletiva para expressar suas demandas, afinal, como aponta Gohn (2011), ao realizar ações sociais coletivas de caráter sociopolítico e cultural, os sujeitos criam sentimentos de pertencimento. Ou seja, a causa e a luta se tornaram parte de suas vidas.

Entre as publicações, encontramos inúmeras reivindicações acerca da “[...] intimidação e a falta de sossego [...]” (O POVO, 22/12/1978, p. 16) dos moradores: “[...] alegam os favelados que os representantes dos proprietários os intimidam com tratores e convites para uma retirada antecipada, para local que eles desconhecem [...]" (O POVO, 22/12/1978, p. 16). Além disto, eles reclamavam da impossibilidade dos homens saírem para procurar outra moradia devido ao medo de que, ao partirem, o trator passasse por cima de seus barracos (O POVO, 22/12/1978, p. 16). Já as mulheres apelavam aos “[ [...] representantes dos donos que a gente nunca viu, para deixarem nós todas em paz [...]” (O POVO, 22/12/1978, p. 16). Esses "representantes", a quem se referiam o periódico e a população, eram, sobretudo, João Furtado e seus "guarda-costas":

Ele queria comprar o terreno, aí houve que quando chegou no INCRA, o terreno era de duas moças velhas, não era do João Furtado, ele não tinha nada a ver, ele era um especulador e como elas não tinham força, aí elas deixaram que ele fizesse isso, porque elas queriam vender a terra, eram duas 
moças velhas, o pessoal falava que era duas freiras depois que eram duas irmãs (risos) ${ }^{11}$.

João Furtado é apontado pelos entrevistados como o "grande vilão" da época, o principal responsável pela perseguição aos moradores através de ameaças e de "capangas". Apesar dos jornais também abrirem espaço para a sua defesa, a atuação dele, enquanto tumultuador, aparece em inúmeras matérias, ratificando a fala dos antigos residentes da José Bastos: “[...] segundo os moradores, os empregados do corretor João Furtado continuam fazendo ameaças, amedrontando até mesmo as crianças [...] 'o pior', disse uma moradora, 'são as arruaças dos capangas. Meus filhos estão apavorados e tem medo de me deixarem só' [...]” (O POVO, 14/02/1979, p. 16). Estes “capangas”, de acordo com Maria Lima, faziam parte da polícia, “[...] o policiamento que pressionou lá foi exatamente do grupo do João Furtado [...]"12 e continuou:

Os homens do João Furtado, ele tinha um certo apoio. Porque assim, a polícia, eu sempre ouvi isso, "eu te protejo e tu me paga", isso até contra o chefe de comando. Um grupo de pessoas favoreceu o João Furtado. Até então, a gente nunca conseguiu descobrir se realmente, a razão maior, se era a central de policiamento que tava a parte disso ou se ele conseguiu manter com algumas pessoas policiais, que foram poucos policiais que apareceram. No início, ele ia só pra amedrontar a gente, não é que ele chegou com polícia, dizendo assim: - Olhe, vocês hoje não vai ficar mais ninguém aqui ${ }^{13}$.

Não podemos afirmar se estes homens eram policiais ou não, mas, analisando os relatos orais e os jornais, percebemos que João Furtado sempre era advertido pelo Departamento de Polícia, mas não foi detido: “[...] o juiz autorizou a Polícia Militar a impedir a presença do corretor, mas 'ele continua lá', afirma o advogado de defesa dos favelados [...]" (O POVO, 09/01/1979, p. 19). Ao contrário, mesmo com todos os pedidos judiciais e as denúncias contra o dito representante das donas do lugar, "[...] diariamente, os empregados do corretor João Furtado, contratado pelas proprietárias do terreno, atemorizavam as famílias, sempre perguntando: Como é, vão sair ou não vão?” (O POVO, 20/02/1979, p. 5). Note-se, também, que o jornal sempre utiliza outros termos mais brandos que "capanga" ou "milícia" ao falar sobre os "ajudantes" do imobiliário.

Na memória de José Almir, o agente de imóveis foi “[...] tipo uma pessoa que era encarregado do terreno, e foi encarregado de tirar as pessoas que tinham invadido, ele dava caminhões, dava camionetas, aquelas pessoas que geralmente desistia de tá lá, ele dava

\footnotetext{
${ }^{11}$ Entrevista com Maria Lima de Carvalho.

${ }^{12}$ Entrevista com Maria Lima de Carvalho.

${ }^{13}$ Entrevista com Maria Lima de Carvalho.
} 
caminhões pras pessoas tirar as coisas de lá [...]". De algum modo, todo o confronto e/ou o comentado "terror" feito por João Furtado, presente nas lembranças dos outros entrevistados, são retratados por José Almir sob uma ótica diferente. Dialogando com Ecléa Bosi (1994), o mesmo fato pode sim ser observado e lembrado de maneira heterogênea, pois fica na memória aquilo que significa: na lembrança de Almir, o corretor apenas cumpria o seu trabalho e ajudava os moradores com a mudança.

Concordamos com a proposição de Bosi (1994), a memória histórica muitas vezes se mistura com a memória familiar e pessoal, a do cotidiano. Portanto, analisando a entrevista de José Almir, percebemos que ele não participou efetivamente da luta de resistência, não esteve presente no dia mais violento do movimento (26 de dezembro de 1978) e foi o primeiro morador a mudar-se para o Conjunto São Miguel, de forma voluntária, um dia antes (23 de abril de 1979) do despejo final, em 24 de abril de 1979. Logo, suas lembranças divergem da maioria dos entrevistados, porque o seu dia-a-dia na José Bastos não foi marcado por experiências traumáticas, como no caso de Maria Lima e do seu esposo, Francisco de Carvalho.

A postura comedida de José Almir se encaixaria na afirmação de Antonio Torres Montenegro (1994): nem todas as pessoas aderem a movimentos de modo inteiramente espontâneo. Nesse caso, ele nem chegou a aderir. Almir, segundo aponta a moradora Maria Lima, estava inserido no grupo que não contribuiu com a mobilização: “[...] aí muita gente, no começo, saíram muito antes da repressão, tipo vai pegar fogo aqui, aí muita gente que não era da luta, foi saindo, foram pra outro canto [...]". Porém, apesar de apresentar uma atitude mais receosa, ele não saiu do terreno antes do despejo final, mesmo com seu não engajamento na causa.

Podemos compreender a acelerada decisão de José Almir de chegar ao conjunto, pela sua fala conformista, “[...] não vim com medo, é que eu sabia que ia despejar e eu tinha, eu queria um lugar pra morar e, principalmente sendo dada, eu sabia que tinha que sair [...]"14. Este morador pode não ter atuado ativamente no movimento de resistência da favela José Bastos, porém ele exerceu um papel importante no Conjunto São Miguel, ao ser um dos líderes comunitários: “[...] aqui foi feita a Associação, eu mesmo passei 16 anos sendo o presidente da Associação e várias e várias coisas a gente construímos depois disso [...]"15. Isto mostra que a luta e as conquistas destes moradores ocorreram numa batalha diária e com a ajuda de todos. Resistir e enfrentar as dificuldades não foram decisões apenas de uma

\footnotetext{
${ }^{14}$ Entrevista com José Almir Monteiro Dias.

${ }^{15}$ Entrevista com José Almir Monteiro Dias.
} 
parcela, todos que se propuseram a ir ao São Miguel também precisaram encarar muitos desafios, os quais serão discutidos adiante.

O desfecho do caso da favela José Bastos ocorreu quando o Juiz da $1^{\text {a }}$ Vara Civil, Francisco Haroldo Rodrigues de Albuquerque, decretou o seu despejo para o dia 24 de abril de 1979. Segundo as informações coletadas nos jornais, “[...] a decisão foi tomada depois que os favelados recusaram o terreno oferecido pelo Governo do Estado, nas proximidades do Frifort (Frigorífico Fortaleza), resolvendo permanecer na José Bastos [...]” (O POVO, 24/04/1979, p. 1). Neste dia, todos os moradores foram retirados da área que foi disputada durante sete meses, entre setembro de 1978 e abril de 1979, pelos chamados "invasores" e seus proprietários. Na justificativa, aparece que a ordem judicial foi dada devido à recusa da oferta governamental e à insistência em continuarem no local, porém, isto vinha ocorrendo desde outubro, a partir da tentativa de "removê-los" para o Conjunto Palmeiras, outro bairro localizado na periferia de Fortaleza:

A Fundação do Serviço Social de Fortaleza está fazendo a remoção de moradores de uma favela recém-implantada na José Bastos. Ameaçados de despejo judicial pelo proprietário do terreno, eles são levados para o Conjunto Palmeiras, em Messejana [...] onde todos podem adquirir terreno em módicas prestações (CORREIO DO CEARÁ, 28/10/1978, p. 3).

A recusa de ir ao Palmeiras foi a primeira resistência feita pelos habitantes da José Bastos, "[...] não queria o Palmeiras porque era muito longe e era muito difícil as coisas e muito esquisito, ninguém foi pra este conjunto, se foi, foi escondido [...]"16. Na verdade, houve algumas pessoas que optaram por ir, porém, pouquíssimas: “[...] até agora, apenas seis famílias concordaram com a transferência para o Conjunto Palmeiras. Enquanto isto, mais 43 ficaram de dar uma resposta, nesse sentido, até o dia 3 de janeiro [...]" (O POVO, 29/12/1978, p. 9). Para os administradores da cidade, essa não aceitação adveio da falta de atuação da FSSF que "[...] não teve forças para evitar o problema, até que se chegasse a presente e grave situação [...]" (O POVO, 15/12/1978, p. 16). Todavia, segundo Maria Lima:

A gente foi até pro Conjunto Palmeiras, não pra morar, foi uma equipe pra lá, foi uma comissão, porque lá também tava sendo debatido a terra para habitar, porque o pessoal de favela mesmo ia pra lá e de outros cantos. Chegaram lá e recusaram o terreno, porque era muito esquisito e dentro de uma mata, aí ficou nesse daqui e a gente vê hoje pela televisão que é um desastre o Palmeiras até hoje, cresceu muito, desenvolveu muito, mas [...].

A fala acima pode ser relacionada com os estudos de Bosi (1994), o sujeito não é um narrador ou uma testemunha histórica, ele também quer julgar o fato. A entrevistada considera

\footnotetext{
${ }^{16}$ Entrevista com Maria Lima de Carvalho.
} 
que apenas o "pessoal de favela" ia a este conjunto, bem como sentencia que o lugar sempre foi problemático. Na citação também se observa certa comparação entre o Palmeiras e o São Miguel, pois "ficar nesse daqui (referindo-se ao São Miguel)" aparenta ter sido mais vantajoso do que ter escolhido o outro. Dadas à rejeição ao Conjunto Palmeiras e a pouca influência da FSSF na José Bastos, a Prefeitura de Fortaleza reconheceu que não conseguiria "removê-la" e entregou a responsabilidade ao Governo do Estado:

O prefeito Luiz Marques, ouvido mais uma vez, sobre o problema, revelou que a "comissão que avaliará o terreno da favela já está trabalhando e que os números serão mostrados ao senhor Governador, já que a municipalidade não tem condições de realizar a desapropriação." Quis dizer o gosto máximo da cidade que a palavra final será do Governo do Estado (O POVO, 29/12/1978, p. 9).

A desistência de tentar resolver este caso não foi apenas porque "[...] a prefeitura não tinha condições de adquirir o terreno que foi avaliado em Cr\$2.496.000,000 [...]" (O POVO, 06/02/1979, p. 12) quando se intentou comprar a área para os ocupantes do local. A decisão foi tomada no final do mês de dezembro de 1978, após a primeira ação efetiva de um despejo através da demolição de algumas casas e do confronto entre moradores e policiais, ocorrido no dia 26 do mesmo mês e ano, episódios que iam de encontro à imagem benéfica e pacífica das remoções feitas pela Prefeitura. Além disto, era a primeira vez que o governo municipal enfrentava uma rápida e forte mobilização contra a sua política de remoção e presenciava a participação popular, bem como a organização de instituições a favor destas pessoas:

Nossa luta começou no dia 12 de dezembro quando fomos vítimas de um despejo que nos pegou de surpresa. Diante desta penosa situação, nós moradores da favela, resistimos e nos organizamos e recebemos o apoio de várias entidades, comunidades e da maioria da população fortalezense quando do lançamento do nosso abaixo-assinado que conta com 16 mil assinaturas (O POVO, 23/04/1979, p. 16) ${ }^{17}$.

De todos os setores que ajudaram e apoiaram o movimento da José Bastos, os participantes mais influentes, isto é, os mais lembrados pelos entrevistados ou presentes nos jornais foram o Dom Aloisio Lorscheider e o Monsenhor Francisco Abelardo Ferreira Lima, representantes da Igreja Católica, através da Arquidiocese de Fortaleza. Além deles, alguns políticos como os deputados Maria Luiza Fontenele e Fausto Arruda, bem como o vereador Bianou de Andrade. Existia ainda o auxílio de alguns estudantes universitários, advogados, professores e assistentes sociais. Muitos destes nomes ainda estão vivos na memória dos moradores como os grandes "heróis" da luta ocorrida contra os policiais e João Furtado.

\footnotetext{
${ }^{17}$ A citação se trata de uma transcrição de trechos de um comunicado (nota) feito pelos líderes do movimento de resistência e que foi distribuído na comunidade.
} 
Todavia, é importante ressaltar que, no ano de 1978, ocorreram eleições. Portanto, a efetiva e marcante participação de políticos e entidades envolvidas com partidos neste movimento pode ser encarada como uma tentativa de autopromoção e garantia de votos:

Sei que nós tinha a deputada Maria Luiza Fontenele que era a favor, tinha o Iranildo Pereira deputado, contra nós só tinha eles mesmo, a polícia, porque o pessoal da Igreja, esses deputados, era tudo com a gente. Tinha a reunião, tinha muita gente, era um exército de gente que era defensor do movimento, era tudo com a gente ${ }^{18}$.

O "exército", citado acima, era diversificado, favorável à causa deles e organizado. Da lista destes benfeitores, Dom Aloisio e Padre Abelardo acompanharam e se dedicaram ao movimento mais que outros colaboradores. Desde o episódio de despejo do dia 12 de dezembro de 1978, os dois passaram a dar suporte e esperança aos impacientes e assustados moradores da favela José Bastos. Participar de trabalhos sociais era uma ação bastante comum da Igreja Católica por todo o país, sobretudo, em lutas contra remoção (MONTENEGRO, 1994). De acordo com Vera Teles (1988), a “opção pelos pobres”, na década de 1960, ainda não era uma política efetiva da Igreja. A mudança ocorre a partir dos anos 1970, quando a instituição deixa de apoiar o Regime Militar $^{19}$ e começa a "[...] estimular a população a resistir à repressão violenta de uma forma pacífica, mas firme [...]” (ALVES, 1985, p. 204).

O padre Abelardo era um mediador entre Dom Aloísio e os moradores, dado a impossibilidade deste, devido à rotina exaustiva, de intervir diretamente. Apesar disso, era o próprio Lorscheider que visitava o governador para pedir revogação de prazos de despejo ou medidas "mais humanas", além de frequentar reuniões e vigílias na favela. De acordo com as entrevistas e os jornais, o padre e o cardeal se empenharam em proteger a segurança física e os direitos dessas pessoas envolvidas no drama da José Bastos, contratando advogados ${ }^{20}$ e vigias para trabalharem na causa. Para Maria Lima, Dom Aloisio Lorscheider "[...] foi quem correu atrás de tudo com o Monsenhor Abelardo e moveu céus e terra [...]"21, dele surgiu também a esperança de comprar a área, bem como todas as informações concernentes ao lugar:

Dom Aloísio botou a proposta pra comprar o terreno, mas aí descobriram que elas deviam ao INCRA que era o valor da terra, aí barrou de novo. Aí o Dom Aloísio veio avisar, "gente agora não dá mais nada, o jeito que tem é

\footnotetext{
${ }^{18}$ Entrevista com Francisco Gonçalves de Carvalho (66 anos), em julho de 2015.

${ }^{19}$ Sobre isto, ver Telles (1988), Montenegro (2010) e Alves (1985).

${ }^{20}$ Segundo a reportagem do jornal $O$ Povo, de 03 de janeiro de 1979, um dos advogados era arquidiocesano e prestava o serviço de modo voluntário. p. 9.

${ }^{21}$ Entrevista com Maria Lima de Carvalho.
} 
sair daqui, não adianta mais comprar essa briga". Aí foi outra confusão, porque a metade queria vim pra cá e outra queria ficar $l^{22}$.

Contudo, segundo a mesma entrevistada, mesmo com o respeito e o carinho aos dois representantes da Igreja, nem todos os moradores foram pacientes e ordeiros com ambos: “[...] tiveram alguns morador que ficou contra o padre Abelardo quando ele foi dizer que não tinha o que fazer, eles não queria sair de lá. Mas nem tinha mais pra onde correr, a gente tinha que sair [...]”. A fala se refere ao dia 22 de abril de 1979, quando o padre Abelardo leu para a população da José Bastos a ordem de despejo final da área, decretada pelo juiz Francisco Haroldo Albuquerque. As últimas frases desta citação demonstram o sentimento de decepção e incapacidade de algumas daquelas pessoas que tanto lutaram e resistiram para permanecer no local, como também refletem a força e o poder do Estado em retirar, afastar e esconder tudo e todos que eram considerados um incômodo.

A reação de revolta contra o padre não se deu por todos os habitantes, pois, como sabemos, alguns decidiram por acatar a decisão e mudaram-se antes do previsto, a exemplo de José Almir. Além disso, a confusão não se deu exatamente pelo despejo, mas sim pela tentativa do padre de convencê-los a não resistir à expulsão e a aceitar a única opção dada pelo governo, o Conjunto São Miguel. Segundo consta nos jornais, essa postura da Igreja adveio da preocupação de que não houvesse violência ou confrontos no dia indicado para a saída deles e, também, para que nenhuma família ficasse sem um lugar para morar: “[...] 'vamos partir do pressuposto de que vocês não consigam a compra do terreno, nem a protelação da medida judicial. Então na segunda-feira, haverá o despejo. Eu fico preocupado com isto. Pergunto: por que vocês não aceitam o terreno doado pelo Governo?' [...]" (O POVO, 22/04/1979, p. 24), perguntou o Padre Abelardo. O periódico prosseguiu com a resposta dos atingidos:

[...] porque lá não serve, a pessoa não vai deixar o canto onde moram, as crianças, em seu barraco, para ir para um lugar onde existem determinadas doenças. Se fosse um lugar melhor, mais central, que tivesse mais condições. Mas, não, ele está dando um lugar que não tem condições. E outra, que nós já gastamos muito em nossas casas e nós não temos mais recursos para gastar lá [...] (O POVO, 22/04/1979, p. 24).

Ao analisar esta reportagem na íntegra, vemos que foi o próprio juiz, Francisco Haroldo Rodrigues de Albuquerque, quem pediu ajuda à Igreja e a alguns políticos, como a Maria Luiza Fontenele, para aconselhar as famílias a não resistirem à remoção. Isto é, de algum modo, a recomendação de não existir (ou se repetir) confronto no dia da retirada, era

\footnotetext{
${ }^{22}$ Entrevista com Maria Lima de Carvalho.
} 
uma forma de apagar ou amenizar a imagem negativa do episódio de 26 de dezembro de 1978 e de perpetuar a ideia ou a memória de que o Estado garantiu a integridade física dos excluídos. Mesmo após a ordem de despejo, eles permaneceram firmes na decisão de não sair do terreno, ainda que o apoio externo da Arquidiocese tivesse "abandonado" a causa: "[...] Dom Aloisio mandou dá o recado que se caso nós não quisesse o terreno que a Dona Luiza tinha arrumado, ele como bispo lavava as mãos [...]"23. A "teimosia" não resultou em conflitos maiores, mas ocasionou o uso de maior força policial no segundo dia de despejo, como nos conta Maria Lima:

O exército veio pra cá a mando, no dia do despejo, porque a força maior foi ele, eles levaram até os cachorros. A revolta de uma parte do povo, eu entendi, mais foi a força como ela (Luiza Távora) pôde tirar o povo de lá. Se ela não tivesse feito isso, eles não tinham saído. Ela não mandou bater, nem prender ninguém, usou a força, foi errado, foi, mas eu entendi. Se o Dom Aloisio tinha dito que se o povo não quisesse sair de lá, "eu não posso fazer nada, o terreno taí, o São Miguel". Aí a Dona Luiza agiu com a força do poder nas mãos, não tão cedendo, "vou fazer minha parte".

Dialogando com as duas fontes aqui utilizadas, as entrevistas e os jornais, percebemos que o primeiro dia de despejo foi realizado apenas com as famílias que não reagiram (contestaram) à retirada. Ressaltamos que a reação não ocasionou violência física, pois não houve confrontos físicos em nenhum dos dias de expulsão, apenas reclamações e protestos. Segundo a fala acima, as pessoas mais revoltadas e inconformadas com a situação só foram despejadas devido à presença do exército, ao afastamento da Igreja e à ação coercitiva de Luiza Távora, esposa do governador. Isto é, sem estes três aspectos, eles continuariam a resistir e a lutar pelo local. Alguns aspectos dessa citação merecem reflexão: a polícia levou os cães para intimidá-los - apesar de não ter ocorrido conflitos -, a fim de assegurar que não houvesse motins, além disso, a entrevistada fala sobre isto, aceitando o modo autoritário como foram removidos, revelando um sentimento de conformidade.

\section{A articulação entre os agentes externos e os moradores: mediação e controle.}

Apesar do "abandono" dos moradores pela Igreja, nos dias mais decisivos da favela José Bastos, o Padre Abelardo e Dom Aloísio Lorscheider restabeleceram o contato com os moradores rapidamente. Ambos passaram a frequentar o Conjunto São Miguel, poucos dias após a mudança, realizando missas, ouvindo as queixas das famílias, fazendo audiências com os lideres do local, entre outras ações: “[...] depois da missa, Dom Aloísio visitou outras casas

\footnotetext{
${ }^{23}$ Entrevista com Maria Lima de Carvalho.
} 
e foi até o local denominado quilômetro 10. Recomendou ao Monsenhor Abelardo que desse um encaminhamento médico a Francisco de Assis, de quatro anos, que se encontra cego. Abençoou os doentes [...]" (O POVO, 14/05/1979, p. 6). Isto é, finalizado os possíveis desentendimentos causados pelos despejos, eles continuaram a atuar enquanto mediadores.

Outros personagens muito comentados pelos moradores foram a Primeira Dama do Estado, Luiza Távora, e os governadores do Ceará, Waldemar de Alcântara (fevereiro de 1978-março de 1979) e Virgílio Távora (março de 1979-março de 1982). Os dois últimos são apresentados como os "vilões", acompanhados de João Furtado e da polícia, sendo responsabilizados por todas as dificuldades enfrentadas pelo movimento de resistência e, sobretudo, por não terem vencido a batalha de permanecer no terreno. Por outro lado, apesar do desabafo supracitado, a imagem de Luiza Távora é representada, quase sempre, positivamente: “[...] Dona Luiza Távora quando ela resolveu abraçar a Zé Basto, ele (Virgílio) deixou na mão dela, não que ela fizesse sem a mão dele, ele sempre vinha com ela, nunca deixou ela só, mas era ela que fazia, tava tudo na mão dela [...]"24.

A citação acima pode ser relacionada com a ideia de Montenegro, “[...] apesar das resistências, das lutas, da repressão, das mortes no período, a memória coletiva está profundamente marcada por uma representação onde apenas um único político interveio na realidade, favorecendo os interesses do conjunto dos trabalhadores [...]" (1994, p. 103). Pois, segundo os entrevistados, tudo que foi distribuído ou realizado era sempre mediado pela Primeira Dama, por isto eles sempre recorriam a ela para solucionar qualquer problema:

Uma comissão formada por dez moradoras da Favela José Bastos esteve na manhã de ontem na residência do governador Virgílio Távora, onde foram recebidas pela primeira dama Dona Luiza Távora, a quem foram pedir para interceder junto ao governador no sentido de que ele encontrasse uma solução para o problema, e os favelados pudessem continuar onde estão $(\mathrm{O}$ POVO, 24/04/1979, p. 16).

O ato de apelar a Luiza Távora provinha das tentativas frustradas de negociar com o governador Waldemar de Alcântara e, posteriormente, Virgílio Távora. Consoante a isto, os moradores sempre enfrentavam alguma perseguição ou impedimento e não conseguiam chegar à sede do governo estadual: “[...] quando praticamente todos já estavam se agasalhando nas carrocerias dos caminhões, um dos oficiais de justiça sacou um revólver e ameaçou o motorista, agredindo-o inclusive com uma tapa, afirmando em seguida que de lá não sairia ninguém [...]” (O POVO, 17/12/1978, p. 38). Segundo as entrevistas, todas as confusões ou repressão ao movimento provinham de João Furtado e não de oficiais ou

\footnotetext{
${ }^{24}$ Entrevista com Maria Lima de Carvalho.
} 
policiais como os periódicos apontam na maioria das notícias. Há de se ressaltar, também, que a lembrança positiva da esposa de Virgílio Távora não é igual à da cônjuge de Waldemar de Alcântara:

\begin{abstract}
A Beatriz Alcântara não fez nada, ela não fez nada. O que aconteceu, foi que no dia que o pessoal fizeram uma comissão pra ir falar exatamente com ele ou era com o prefeito, quando eles foram subindo no caminhão para falar com o governador, a comissão era o Albino, o líder, né? Nessa hora, chegou dois ou foi três policiais tudo com aquele cassetete, né? $\mathrm{E}$ aí barrou o caminhão e disse que não ia mais ninguém para lugar nenhum ${ }^{25}$.
\end{abstract}

Em síntese, essa tentativa de ir ao Palácio da Abolição foi motivada pela demolição de mais de 300 casas na José Bastos no dia anterior. Eles queriam conversar com o Governador para negociar a não derrubada de suas moradias, mas foram duramente atrapalhados de visitalo durante a manhã, tendo conseguido o encontro apenas no final da tarde. Segundo os entrevistados e os jornais, o impedimento iniciou com a obstrução da saída do caminhão (fretado por meio de doações voluntárias) onde os líderes do movimento estavam, supracitado acima. A segunda investida também foi impossibilitada por “[...] dois soldados armados de metralhadoras [...]” (O POVO, 17/12/1978, p. 38), pois, “[...] eles ainda tentaram apanhar os ônibus que fazem a linha da Avenida José Bastos, mas o Oficial de Justiça interferiu uma vez, ameaçando o motorista do coletivo [...]” (O POVO, 17/12/1978, p. 38). Supomos, novamente, que este "Oficial de Justiça" tratava-se, na verdade, do corretor de imóveis João Furtado ou, provavelmente, alguém atuando a mando dele.

O papel da Luiza Távora consistia em conciliar ou acalmar o movimento, ou seja, deixar as famílias anestesiadas, tanto pela esperança de permanecerem no terreno quanto pela sensação de segurança e de assistência dadas a elas. A expectativa de vencer esta luta era alimentada por dois fatores: primeiro, pela participação de vários agentes externos que os incentivavam a comprar o terreno ou a batalhar pela desapropriação da favela e, também, pelos dois adiamentos dos despejos concedidos em 16 de dezembro de 1978 (ajuda da arquidiocese) e em 19 de fevereiro de 1979 (solicitado pelo governador Waldemar de Alcântara, porém reconhecido pelos entrevistados como ação de Luiza Távora, antes mesmo de ser a Primeira Dama). A primeira prorrogação deu-se, como apontam os jornais, devido às festas de Natal e Ano Novo, período em que o município ocupou-se em preparar a cidade para o comércio, o turismo e o lazer, setores que mereciam toda a atenção da Prefeitura, logo, qualquer outro problema podia esperar.

\footnotetext{
${ }^{25}$ Entrevista com Maria Lima de Carvalho.
} 
Entretanto, mesmo que a intenção fosse pacificar os moradores e tranquilizar as outras partes envolvidas, o resultado do primeiro retardamento (16/12/1978) foi a ocorrência do episódio mais violento da história dessa comunidade, o tiroteio entre os comparsas de João Furtado, a polícia e alguns habitantes da José Bastos, que acometeu com paralisia um dos líderes do movimento, Francisco Gonçalves de Carvalho. Em outras palavras, o adiamento alimentou as esperanças daquelas pessoas, incentivando-as a lutarem mais pelo local, em contrapartida, esta mínima conquista de 60 dias foi interpretada como uma possibilidade de perda do terreno pelos proprietários e seus representantes, os quais intensificaram a intimidação sobre os moradores até resultar no conflito:

Quando foi o dia 26 de dezembro de 1978, aí, eles chegaram lá, aí o Delegado lá do Distrito da Parangaba, quem disse foi o Albino, que era o cara da associação nossa, o líder, né? E presidente também da Associação, aí ele disse que se o João Furtado chegasse lá, era pra ir pra lá, que ele também queria pegar ele, que ele não podia fazer isso com o pessoal de lá, não, porque ele num era dono de terreno. Mas aí, quando dei fé, eles tavam derrubando a casa de um homem, que foi uns homens da polícia pago, fora parte, lá do $5^{\circ}$ Batalhão, pra poder tirar os véi de uma casa lá, aí eu tava dormindo quando os menino me chamou pra ir olhar, pra ir com eles lá, aí eu fui, né? Quando cheguei lá, tavam tirando, os véi tavam chorando, pra tirar as coisas de lá e os policial lá, e um pessoal dele lá, que era pago, né? Aí lá já tinha poucas famílias, não tinha muito mais não, aí, eu sei que nesse dia mesmo, aí nós saímos, aí o Albino anotou o número da placa aí saiu, aí no lugar que tinha um depósito de material já tinha saído fora e tava só o limpo, né? Aí eu saí mais a negrada, o Albino disse que ia pro $5^{\circ}$ Distrito da Parangaba, mas só que pra mostrar o Delegado, né? Aí eles ouviram e entraram no carro e nós saímos de perto, só que eu não ia pra lá não, ia de lá pra casa, né? Achei muito quente e eu tinha ido com meus dois menino pequeno, não dava pra ir. E aí quando eu dei fé o Albino disse pra eles que a polícia vinha, né? Eles desceram do carro quase correndo e começaram a bater nele, né?, no Albino, que era o líder, ele disse isso, né? Aí ficaram batendo nele, aí começaram a atirar, começaram aquele tumulto de gente, aquele rebuliço todo. Aí eu peguei essa bala, atiraram em mim nas costas, na coluna, nessa hora eu já cai paralítico. Aí eu fui pro hospital, pro Frotão ${ }^{26}$.

A fala acima narra o maior conflito ocorrido no movimento de resistência da José Bastos, através da perspectiva de um dos líderes dessa luta. Por ela, ratificamos a presença da polícia, de João Furtado, da falta de tranquilidade dos moradores, das ações violentas de despejos, da perseguição e mobilização de outro representante da favela, Albino, bem como as marcas físicas e traumáticas deixadas no corpo e na memória de Francisco Gonçalves. Por outro lado, a passagem acima vai totalmente de encontro aos discursos da imprensa, principalmente, em um aspecto: enquanto Francisco discorre sobre o abuso de poder por parte dos policiais ao tentarem retirá-lo, mesmo que em 16 de dezembro eles tivessem ganhado o

\footnotetext{
${ }^{26}$ Entrevista com Francisco Gonçalves de Carvalho.
} 
direito de permanecer por dois meses no local, os jornalistas tendem a diminuir a participação repressiva da polícia nas notícias, a ocultar as ações de João Furtado e a ressaltar a "agressividade" dos moradores:

\begin{abstract}
Um desencontro nas informações sobre a saída dos favelados da Avenida José Bastos gerou ontem um pequeno conflito, mas que poderia ter tomado proporções maiores, não fora o reforço policial exigido e a saída daqueles mais revoltados para o Hospital Distrital de Parangaba, a fim de receberem atendimento de urgência. Tudo começou quando alguns policiais chegaram àquela favela por volta das $14 \mathrm{~h} 30 \mathrm{~min}$, com ordens superiores de desocuparem as casas. Os favelados não atenderam às solicitações dos policiais, pois segundo eles o Juiz havia dado 60 dias para eles se mudarem. Alguns dos exaltados entraram em luta com os policiais, saindo um baleado e vários favelados atingidos levemente no entrevero que quase se transformou em batalha campal (CORREIO DO CEARÁ, 27/12/1978, p. 1).
\end{abstract}

Analisando as divergências e convergências nos dois discursos acima, observa-se, por exemplo, a ciência por parte dos habitantes de seu direito de permanecer no local. Isto, possivelmente, ocasionou a agitação dos líderes do movimento e a tentativa de impedir a derrubada de casas. Percebe-se, também, a atuação dupla da polícia, ora cumprindo seu papel de assegurar a integridade física da população da José Bastos ora coagindo, reprimindo e os intimidando. Como vimos, algumas entrevistas apontam uma ligação entre policiais e o João Furtado, como se aqueles trabalhassem para este nas horas de folga do serviço. Nota-se, ainda, apesar de todos os eufemismos utilizados na matéria do periódico, que a confusão provocou um conflito armado com vários baleados e feridos, entre civis e policiais.

\title{
Perderam a batalha, mas não a guerra
}

É inegável que esse ocorrido foi o ápice da história da favela José Bastos, mas, desde a primeira conquista do adiamento do despejo, os ânimos vinham se exaltando. De acordo com Maria Lima, após a Justiça ter concedido mais sessenta dias para a retirada e ter advertido João Furtado, “[...] para não mexer mais com o povo da Zé Basto [...]”, o agente imobiliário e seus "capangas" não deram mais trégua. A advertência do juiz levou o representante dos proprietários e o seu advogado, Dr. Leônidas de Freitas, a irem se defender publicamente no jornal O Povo, “[...] para enfatizar que não estava havendo violências na ação judicial, pois as casas demolidas, até agora, se achavam desabitadas [...]" (O POVO, 16/12/1978, p. 13). Esta defesa baseou-se na primeira decisão do juiz Dr. Edgard Carlos Amorim sobre o caso, a de reintegração de posse do terreno, estabelecida alguns dias antes da nova ordem. 
No dia seguinte, 17, os moradores tentaram ir até o Palácio da Abolição para pedir que o governador fizesse cumprir a decisão judicial de parar por sessenta dias a derrubada das casas ou, se possível, deixasse-os permanecer no terreno definitivamente. Entretanto, apesar da ida ao Palácio, os despejos e a presença indesejada de João Furtado e da polícia continuaram: “[...] muito embora o juiz Edgard Carlos Amorim, da $1^{\text {a }}$ Vara Cível de Fortaleza, tenha dado entrevista a este jornal, dizendo que sustara, por conta própria, os despejos, na favela da Avenida José Bastos, a ação judicial prosseguiu durante o dia de ontem, garantida pela Polícia [...]" (O POVO, 19/12/1978, p. 16).

Os Oficiais de Justiça, apoiados pelos proprietários do terreno, continuaram a cumprir o mandado de reintegração de posse até o dia 19 de dezembro de 1978, valendo-se da desculpa de um suposto atraso no recebimento do documento com a suspensão da ação de despejo e da autorização de permanência dos moradores por mais 60 dias: "[...] os funcionários do Fórum revelaram que, até ontem, nada haviam recebido oficialmente sobre o novo prazo, diante do que eram forçados a prosseguir com a operação [...]" (O POVO, 19/12/1978, p. 16). Porém, mesmo com a nova ordem judicial, as demolições e as ameaças persistiram até o dia fatídico de 26 de dezembro. Aparentava-se, portanto, que a Justiça não se importava com o descumprimento de sua autoridade, ao mesmo tempo em que isentava os transgressores de qualquer punição. O jornal, por exemplo, até tenta justificar a expulsão dos moradores, apesar da existência da suspensão, criando para isso argumentos que não tinham base jurídica:

[...] a medida liminar está em pleno vigor. Apenas foi suspensa pelo prazo de 60 dias, contudo, nada impede que as providências requeridas sejam adotadas. Ressalte-se que não se pode usar dentro desses 60 dias a força" [...] $\mathrm{Na}$ ordem judicial, o que desconhecem os favelados e é um dos motivos da presença da Polícia é a autorização aos proprietários para que permitam retirar os favelados que assim o desejarem, pondo a disposição dos moradores capatazia (O POVO, 27/12/1978, p. 12).

Em síntese, a lei de suspensão do despejo era apenas um disfarce para tranquilizar os moradores da favela José Bastos e, sobretudo, uma maneira de fazê-los sair de modo voluntário e ordeiro. Entretanto, esta prorrogação foi interpretada pelos líderes do movimento de forma esperançosa, como se a medida tivesse lhes dado tempo para propor a compra do terreno. Eles também acreditavam que a ordem judicial garantiria o afastamento da polícia e de João Furtado do local, mas não foi o que ocorreu. Na interpretação (discurso) dos jornalistas, o juiz tinha concedido apenas mais tempo para eles abandonarem o lugar, não havendo irregularidade em qualquer ação realizada pelo representante dos proprietários ou 
pela polícia, já que a única restrição favorável aos residentes era a proibição de desalojá-los à força neste período de 60 dias, como pode ser observado na passagem supracitada.

Outro fator que contribuiu para o conflito foi a desobediência de alguns moradores, os quais desacataram a ordem estabelecida pelo juiz de não alterar nada no local, após a suspensão das demolições, isto é, que ninguém construísse mais nenhum barraco nem ocupasse as casas já desocupadas. O descumprimento desta ordem por parte dos habitantes da José Bastos, provavelmente ocorreu como uma reação contrária à permanência dos despejos. A medida visava impedir que o lugar recebesse mais pessoas ou o retorno de famílias já transferidas. Além disso, o objetivo era frear as reivindicações do movimento até a posse de Virgílio Távora no Governo do Ceará e, assim, a de sua esposa Luiza Távora como responsável pela assistência social do Estado, pois ela já figurava na solução destas questões sociais. Porém, nem João Furtado nem os moradores cumpriram o acordo feito pelo Juiz e o resultado foi o confronto que vitimou um dos líderes da favela:

Eles lá (moradores) estão proibido de mover sequer uma estaca, paralisa tudo, fica todo mundo quieto. Mas o que foi que aconteceu? Todo dia ia gente embora de lá e tinha ficado uns terreno lá muito bom, ele com os olhos esperto, tava desmanchando uma casa de noite, isso no dia 24 de dezembro de 78, mas não era pra mexer mais em nada, a gente tava aguardando a mulher (Luiza Távora) entrar. Isso ia dá confusão. Passa o dia 24, 25, isso era domingo, ai quando foi dia 26 , dia de trabalho, a polícia chegou meiodia, ele (Francisco Gonçalves) foi trabalhar e voltou. Aí foi nesse dia que aconteceu o acidente com ele, era dia 26 de dezembro, ai foi nesse dia que a policia chegou, os capangas do João Furtado mais uma vez chegaram e invadiram a casa de um casal de idosos, ai eles se juntaram todos, a comissão, né? Foram pra cima e aconteceu tudo isso ${ }^{27}$.

No discurso oficial, a confusão se deu por volta de 15 horas, quando "[...] oficiais de justiça, protegidos por duas patrulhas da Polícia Militar, derrubavam um casebre fechado. Dois favelados, residentes em área distante do local se aproximaram na tentativa de evitar a derrubada dos casebres [...]" (O POVO, 27/12/1978, p. 12). As duas pessoas a que o jornal se refere são Albino e Francisco Gonçalves, dois dos representantes dos moradores. Baseado no fato de apenas este morador e um policial terem sido baleados, o jornal afirma que houve somente dois tiros durante o conflito: "[...] da confusão surgiu o primeiro tiro, seguindo-se do desarmamento de um soldado e de mais um tiro. Ao final, dois estavam feridos [...]" (O POVO, 27/12/1978, p. 12). Além disto, o periódico deu mais importância aos ferimentos dos soldados e à questão do sumiço da arma de um deles, pouco informando sobre a integridade física de Francisco Gonçalves:

\footnotetext{
${ }^{27}$ Entrevista com Maria Lima de Carvalho.
} 
A Delegacia do $8^{\circ}$ Distrito registrou o tiroteio da José Bastos. Estão feridos o soldado Francisco das Chagas Freire e o morador Francisco Gonçalves Carvalho, de 28 anos, casado. Também foram medicados, vítimas de pedradas, o soldado Sebastião Pedro da Silva, de 21 anos, casado e o Cabo Diomédio Domingos Batista, de 38 anos, casado. Há inquérito aberto para apurar, também o desaparecimento de uma arma de propriedade da Polícia Militar (O POVO, 27/12/1978, p. 12).

Segundo os entrevistados, os tiros eram constantes no local, tanto no dia 26 de dezembro quanto em outros momentos e, contrariando a reportagem acima, existiram outros moradores feridos: "[...] teve troca de tiros antes, toda hora eles atiravam, intimidava o pessoal, batiam, no dia do caminhão que a gente ia pra falar com o Governador, eles começaram a atirar, a polícia espancou uma menina lá [...]"28. Por outro lado, a suspeita de um morador ter portado a arma desaparecida parece confirmar-se, “[...] teve um "baixinho” lá que saiu correndo, quando ele passou na minha porta, ele vinha com a mão na cintura, ele me disse que era uma pancada que ele tinha levado, mas me disseram que ele tinha carregado uma arma de um polícia na hora, mas eu não sei [...]"29 . A ação violenta da polícia (ou dos capangas de João Furtado) e a reação do povo podem ser explicadas utilizando os conceitos de Certeau (2014), estratégias ou táticas.

Em resumo, as estratégias dos que estavam "cumprindo" o mandado de reintegração de posse eram desalojar todos os que quisessem sair, desmontar todas as casas que estivessem desabitadas e tentar convencê-los, por meio das ameaças e da intimidação, a partirem do terreno. Em contrapartida, as táticas do movimento de resistência era reunir esforços para lutar contra as investidas de despejo, formar uma comissão junto à Igreja para protestar sobre os abusos das estratégias acima e revidar, se fosse preciso, qualquer ato violento, a exemplo do que aconteceu no dia 26 de dezembro, "[...] quando alguns favelados foram espancados e feridos a bala, sendo obrigados ao revide [...]" (O POVO, 28/12/1978, p. 9).

Depois da confusão, a Prefeitura de Fortaleza, intensificou os trabalhos de cadastramento das famílias que desejassem comprar um lote no Conjunto Palmeiras, entretanto, como comentamos, houve uma grande recusa desta opção. Há até mesmo uma denúncia no jornal $\mathrm{O}$ Povo que acusou os moradores de terem se tornado agressivos com os agentes do governo municipal (O POVO, 29/12/1978, p. 9). Porém, de acordo com Maria Lima, a população da José Bastos eram os verdadeiros agredidos devido às constantes ameaças de despejo: “[...] o terror era a questão do abaixo-assinado, dizendo que a gente não ia ficar, querer que a gente saísse das nossas casas, às vezes eles chegavam com o caminhão

\footnotetext{
${ }^{28}$ Entrevista com Francisco Gonçalves de Carvalho.

${ }^{29}$ Entrevista com Maria Lima de Carvalho.
} 
dizendo que quem quisesse sair, eles tavam ali pronto pra levar para onde a gente quisesse $[\ldots]^{, 30}$.

A agressão não era física, ela era psicológica. De acordo com as entrevistas e os próprios jornais, muitos não conseguiam dormir, assustados e preocupados com a iminência de um novo conflito ou da derrubada de suas casas enquanto outros protestavam contra a presença policial, “[...] principalmente porque estão sempre armados até os dentes, com revólveres, cassetetes e metralhadoras [...]" (O POVO, 28/12/1978, p. 9). Ou seja, a intranquilidade e o medo causavam duas reações neles: fortaleciam o movimento e a coragem de uns, mas também retirava a paz de muitos.

A garantia de levá-los "aonde eles quisessem", exposta na fala de Maria Lima, era um modo indireto (uma coerção simbólica) de fazê-los sair de forma voluntária, caso persistisse a rejeição pelo Conjunto Palmeiras. Em janeiro de 1979, as reclamações continuaram, tanto por parte dos donos do terreno quanto dos ocupantes. Não teve outra ocorrência violenta de troca de tiros, mas os atentados, as ameaças e as perturbações se mantiveram constantes, como vemos em várias matérias jornalísticas: “[...] não saio nem mais para trabalhar (lavadeira) ficando o dia todo aqui sentada, montando guarda para que não aconteça com minha casa o que ocorreu com a Dalva que saiu de casa e não teve para onde voltar pois os homens derrubaram a casa dela enquanto estava fora [...]" (CORREIO DO CEARÁ, 19/01/1979, p. 12). Dez dias antes, outro diário tratava de um problema semelhante:

\begin{abstract}
A última novidade na favela da José Bastos é que seus moradores já não podem dormir a noite, pois correm o risco de ver cair sobre as suas cabeças o telhado dos barracos onde vivem. Eles não sabem o autor (ou autores) da afronta, informam apenas que alguns dias, todas as noites, pedras grandes são jogadas no teto das casas furando telhas e assustando as crianças $(O$ POVO, 09/01/1979, p. 19).
\end{abstract}

Segundo Maria Lima, a luta pela permanência era diária e a participação das mulheres foi um dos fatores decisivos para a realização do movimento. Pois, eram elas que mais apoiavam a causa, sem abrir mão da resistência e da defesa de suas casas: “[...] vinha as mulheres, vamos fazer a organização, os homens saíam para trabalhar e as mulher ficava, as mulher no dia do pega fogo lá (26/12) foi pau pra dá em dez lá, só via mulher lá no meio. Na época lá as mulher lutava, eram guerreira mesmo, as mulher era valente [...]”. Esse engajamento advinha da necessidade de ter um lugar seguro para criar seus filhos e para habitar. Muitas moradoras, segundo Maria Lima, eram chefes de família e, através do caso

\footnotetext{
${ }^{30}$ Segundo a entrevistada, João Furtado intimidava os moradores a partir do porte de um abaixo-assinado supostamente advindo dos proprietários do terreno.
} 
José Bastos, enxergavam a oportunidade de conseguir a tão sonhada casa própria, por isto, elas lutavam junto aos homens pela conquista deste direito: “[...] depois das primeiras movimentações, homens e mulheres, armados de pau, saíram para a briga no meio da rua [...]" (CORREIO DO CEARÁ, 27/12/1978, p. 8).

Porém, mesmo com a incansável sentinela das mulheres, o local continuou a ser palco de disputas. Ainda em janeiro, os donos do terreno construíram um muro de quarenta metros de comprimento ao redor da área ocupada pelas famílias da José Bastos para, segundo eles, evitar o surgimento de novos casebres. Todavia, a medida objetivava controlar a entrada e a saída dos moradores, além de ter se tornado mais um causador de tumultos, queixas e agressões. Pois, junto ao muro, ainda existiam os vigias que, ao cumprir as ordens dos proprietários do lugar, provocavam os residentes, “[...] batendo nas portas nos casebres e perguntando quando o pessoal vai sair, ameaçando e, às vezes, até agredindo [...]" (O POVO, 12/01/1979, p. 8). Esta situação de controle e "prisão" perdurou até a queda do muro, no final do mês de fevereiro:

O muro, ele não foi derrubado, eles construíram realmente o muro, como se tivesse cercando a gente, era a maneira mais fácil, eu acho que eles achavam que cercando a gente era uma repressão de você sair, mas nem por isso o povo temeu. Aconteceu isso aí (hostilidade contra eles), como aconteceu com muita gente, do povo chegar e eles não deixavam mais entrar, a polícia não deixava, nem entrava e nem saia ${ }^{31}$.

Tanto a construção quanto o fim do muro foram motivos de desavenças entre o corretor João Furtado e os moradores. O imobiliário acusou estes de o terem derrubado com a ajuda da arquidiocese de Fortaleza e da Deputada Maria Luiza Fontenele, mas os acusados defenderam-se afirmando que o muro caiu em consequência das chuvas e da falta de solidez (cimento) na estrutura dele, da sua construção improvisada. A própria fala de Maria Lima, acima, expressa que a parede não foi derrubada, justificando e reiterando a defesa empregada há quase quarenta anos: “[...] a acusação era um pretexto para a nova incursão, visando a desalojá-los, meta maior dos interessados [...]" (CORREIO DO CEARÁ, 01/03/1979, p. 9). Por outro lado, a queda deste muro pode também ter sido obra de alguns habitantes da José Bastos, uma vez ela ocorreu logo depois do anúncio da segunda decisão judicial em adiar novamente o despejo:

O juiz Francisco Haroldo Rodrigues de Albuquerque, da $2^{\text {a }}$ Vara Cível, prorrogou, ontem, em mais de 60 dias, o prazo para a demolição dos casebres da favela José Bastos. A notícia trouxe grande alegria aos favelados, que desde dezembro vivem momentos de angústia [...] Agora, a

\footnotetext{
${ }^{31}$ Entrevista com Maria Lima de Carvalho.
} 
desapropriação do terreno em questão poderá ser estudada no governo Virgílio Távora o que dá muitas esperanças aos humildes moradores da favela. Eles ficaram tão contentes que convidaram o cardeal Aloisio Lorscheider para presidir uma concelebração eucarística de ação de graças no local, dentro em breve (O POVO, 20/02/1979, p. 1).

A alegria de ganharem mais 60 dias de permanência no terreno, possivelmente, pode tê-los motivado a derrubarem o muro. Tanto por acreditarem que ficariam definitivamente no local e, portanto, teriam o direito de ir e vir, sem a interferência de uma cerca de contenção, bem como por se sentirem protegidos pela Igreja e pelos outros apoiadores da causa, já que a lei estava mais uma vez "em favor deles". Além disto, como já vimos, eles depositavam muita credibilidade no trabalho social da esposa de Virgílio Távora e confiavam, piamente, que a posse do governador e da Primeira Dama Luiza Távora seria a garantia de conseguirem continuar na José Bastos ou de serem remanejados, ao invés de despejados:

A Dona Luiza Távora, a primeira dama, ela já tinha regularizado a situação diante da justiça. Ela não tinha ainda assumido o governo, ela já tinha dado uma trégua junto ao governador que era o Waldemar de Alcântara, que até então deixasse o povo da Zé Basto calma, que assim que ela assumisse o governo, o primeiro trabalho dela era remover o pessoal da Zé Basto ${ }^{32}$.

Considerando a posse de Virgílio, em 15 de março de 1979, e a transferência deles para o Conjunto São Miguel, em 24 de abril do mesmo ano, a promessa acima parece ter sido cumprida e de forma bem rápida. É provável que a urgência em se resolver esta questão tenha sido uma tentativa de parar o movimento da José Bastos, o qual já influenciava outras comunidades como a Verdes Mares (localizada no Papicu) a lutar por sua moradia (O POVO, 13/03/1979, p. 9). Para Francisco Gonçalves, a luta deles foi “[...] um espelho para todas as favelas que têm, que foi retirada, né? [...]”. Em sua memória, todas as resistências aos despejos que ocorreram após a da José Bastos espelharam-se nesta experiência. Assim, a partir de 1978, os menos favorecidos não mais hesitaram em lutar pelos seus direitos.

As ajudas deram-se de maneira efetiva para assegurar que eles não voltassem a ocupar outros terrenos, bem como para convencê-los de que foram beneficiados e assistidos. Hoje, quase quarenta anos depois do ocorrido, Maria Lima indica certa insatisfação em relação à Primeira Dama. Em sua fala, a moradora releva a coerção empregada no dia do despejo, julgando que a imposição foi até necessária, pois, sem isso, eles não teriam saído. Por outro lado, a entrevistada considera injustiça o fato de Luiza Távora ter construído as casas de outros conjuntos de alvenaria enquanto que no São Miguel foi de taipa:

\footnotetext{
${ }^{32}$ Entrevista com Maria Lima de Carvalho.
} 
A questão maior foi a repressão, a gente não queria vim não queria entender, mas eu entendi, não entendi na época, porque a gente fica meio avuado nesse ponto e a outra parte que eu achei negativa, porque quando você recebe, você tem assim gratidão, mas depois você vai apurar os casos, eu achei que quando ela removeu pra cá, ela podia ter feito as casas de tijolo, nem que demorasse, foi feita de taipa, pra botar os morador dentro, agora vamos fazer de tijolo, como ela fez no Santa Teresinha e São Francisco, só o São Miguel ficou as casinhas de taipa ${ }^{33}$.

Pela passagem acima, ainda podemos refletir sobre o quanto a memória muda com o tempo, como ela vai sendo construída, refletida, (re)ssignificada e narrada através da relação passado-presente (THOMSON, 1997). Em 1979, o sentimento era, sobretudo, de gratidão pelo lote e o barraco recebidos, hoje eles se sentem injustiçados com a experiência observada em outras comunidades, ainda que enalteçam os feitos da esposa do governador Virgílio Távora. Entre as realizações de Luiza Távora, destacam-se a convocação de policiais para ajudar no levantamento das moradias, a doação de telhas e de outros materiais de construção, o fornecimento de alimentos e de carros-pipas, bem como os abrigos provisórios enquanto as moradias eram construídas.

De modo semelhante à erradicação de muitas comunidades, a favela José Bastos foi mais uma experiência de exclusão socioespacial daqueles que, de acordo com a lógica urbanística, por não terem condições econômicas também não poderiam ocupar os melhores espaços da cidade. Esta prática de retirar, afastar e esconder a população pobre das grandes metrópoles, expulsando-a para munícipios vizinhos ou para zonas muito afastadas das áreas centrais, foi bastante comum durante a década de 1970, em todo o Brasil. O conjunto São Miguel é apenas um exemplo dessa estratégia socioespacial que priorizava a estética ao invés dos cidadãos economicamente desfavorecidos.

Há, portanto, uma política de descaso disfarçada de amparo, pois a moradia e os serviços sociais recebidos não eram suficientes para o bem-estar desta população excluída. Além disto, eles ainda tiveram que lutar para ter acesso aos equipamentos urbanos (escola, água encanada, hospital, energia elétrica, esgoto etc.) e para se adaptar às novas rotinas e às dificuldades, quando da chegada deles a este conjunto habitacional.

\section{Entrevistas}

CARVALHO, Francisco Gonçalves de. Francisco Gonçalves de Carvalho: depoimento [jul. 2015]. Entrevistadora: Angerlânia da Costa Barros. Caucaia: 2014. Arquivo em MP4.

\footnotetext{
${ }^{33}$ Entrevista com Maria Lima de Carvalho.
} 
CARVALHO, Maria de Lima. Maria de Lima Carvalho: depoimento [mai. 2017]. Entrevistadora: Angerlânia da Costa Barros. Fortaleza: 2017. Arquivo em MP4.

DIAS, José Almir Monteiro. José Almir Monteiro Dias: depoimento [jun. 2016]. Entrevistadora: Angerlânia da Costa Barros. Fortaleza: 2016. Arquivo em MP4.

SOUSA, Maria de Lourdes Rodrigues de. Maria de Lourdes Rodrigues de Sousa: depoimento [jul. 2015]. Entrevistadora: Angerlânia da Costa Barros. Fortaleza: 2015. Arquivo em MP4.

\section{Referências bibliográficas}

AINDA a favela da José Bastos: Fundação denuncia movimento nocivo. O Povo, Fortaleza, 29 dez. 1978. Caderno A, p. 9.

ALVES, Maria Helena Moreira. Estado e oposição no Brasil (1964-1984). 3. ed. Petrópolis, RJ: Vozes, 1985.

BARREIRA, Irlys Alencar Firmo. O reverso das vitrines: conflitos urbanos e cultura política em construção. Rio de Janeiro: Rio Fundo Editora, 1992.

BESERRA, Bernadete de L. Ramos. Movimentos sociais no campo do Ceará (1950-1990). Fortaleza: Imprensa Universitária, 2015.

BONDUKI, Nabil Georges. Origens da habitação social: Arquitetura moderna, Lei do Inquilinato e difusão da casa própria. São Paulo: Estação Liberdade: FAPESP, 1998.

BOSI, Ecléa. Memória e sociedade: lembranças dos velhos. 3. ed. São Paulo: Companhia das Letras, 1994.

BRAGA, Elza Maria Franco. Os labirintos da habitação popular: conjunturas, programas e atores. Fortaleza: Fundação Demócrito Rocha, 1995.

CINCO mil favelados enxotados da José Bastos. O Povo, Fortaleza, 15 dez. 1978. Caderno A, p. 16.

CONFLITO na José Bastos: favelados contra polícia. Correio do Ceará, Fortaleza, 27 dez. 1978. Caderno A, p. 1.

CONTINUAM os despejos na favela da J. Bastos. O Povo, Fortaleza, 19 dez. 1978. Caderno A, p. 16.

DOM Aloísio vai ao conjunto e pede união. O Povo, Fortaleza, 14 mai. 1979. Caderno A, p. 6.

FAVELA da José Bastos: será pedido novo prazo. O Povo, Fortaleza, 06 fev. 1979. Caderno A, p. 12.

FAVELA José Bastos vive momentos de grande tensão. O Povo, Fortaleza, 23 abr. 1979. Caderno A, p. 16.

FAVELA da José Bastos: moradores pedem socorro. O Povo, Fortaleza, 22 dez. 1978. Caderno A, p. 16.

FAVELADOS da José Bastos terão mais sessenta dias. O Povo, Fortaleza, 16 dez. 1978. Caderno A, p. 13.

FAVELAS. O Povo, Fortaleza, 12 out. 1978. Caderno A, p. 3.

FIM ou começo de um drama de quatro meses? O Povo, Fortaleza, 22 abr. 1979. Caderno A, p. 24.

FUNDAÇÃO remove favelados para o Conjunto Palmeiras. Correio do Ceará, 28 out. 1978. Caderno A, p. 3.

GOHN, Maria da Glória. Movimentos sociais na contemporaneidade. In: Revista Brasileira de Educação. Rio de Janeiro, v. 16, n. 47, mai-ago. 2011. p. 333-361.

GONÇALVES, J. Ocupar e resistir: problemas de habitação no centro pós-moderno (SP). Dissertação (Mestrado em Geografia), Universidade de São Paulo, São Paulo, 2006.

HOJE o dia D da favela José Bastos. O Povo, Fortaleza, 24 abr. 1979. Caderno A, p. 1. 
JUIZ da mais 60 dias aos favelados da José Bastos. O Povo, Fortaleza, 20 fev. 1979. Caderno A, p. 5.

MONTENEGRO, Antonio Torres. História oral e memória: a cultura popular revisitada. 3. ed. São Paulo: Contexto, 1994.

MORADOR da favela agredido por vigia. O Povo, Fortaleza, 12 jan. 1979. Caderno A, p. 8.

MORADORES da José Bastos denunciam perseguições. O Povo, Fortaleza, 14 fev. 1979. Caderno A, p. 16.

RECUSADO o terreno do Frifort. O Povo, Fortaleza, 24 abr. 1979. Caderno A, p. 16.

REIS, José Roberto Franco. O coração do Brasil bate nas ruas: a luta pela redemocratização do país In: PONTE, Carlos Fidélis; FALLEIROS, Ialê (orgs). Na corda bamba de sombrinha: a saúde no fio da história. Rio de Janeiro: Fiocruz/COC; Fiocruz/EPSJV, 2010.

REPRESSÃO aos favelados da Avenida José Bastos. O Povo, Fortaleza, 17 dez. 1978. Caderno A, p. 38.

TELES, Vera da Silva. Anos 70: experiências, práticas e espaços políticos. In: KOWARICK, Lúcio (org.). As lutas sociais e a cidade. São Paulo: Paz e Terra, 1988.

TERRORISMO contra os favelados da J. Bastos. O Povo, Fortaleza, 09 jan. 1979. Caderno A, p. 19.

THOMSON, Alistair. Recompondo a memória: questões sobre a relação entre a história oral e as memórias. Revista Projeto História. São Paulo, n 15, 1997. p. 51-84.

TIROTEIO com dois baleados na favela da José Bastos. O Povo, Fortaleza, 27 dez 1978. Caderno A, p. 12. 